\title{
Can Action Research Arm Test Predict Functional Independence in Addition to Motor Functions in Stroke Patients?
}

\author{
이 Muhammed Nur Ögün, ${ }^{1}$ (1) Ramazan Kurul²
}



\begin{abstract}
Objective: To investigate the ability of the Action Research Arm Test (ARAT) scores to predict functional independence in the evaluation of upper extremity motor functions in stroke patients.
\end{abstract}

Methods: A total of 59 patients with stroke with a mean age of $61.10 \pm 9.12$ were included in this study. Forty-one $(69.5 \%)$ of the patients were male, and 18 (30.5\%) were female. After obtaining the demographic data of the patients who were followed up in the stroke outpatient clinic after the stroke, upper extremity functions were evaluated using ARAT test, and functional independence was evaluated with Performance Assessment of Self Care Skills (PASS) and Functional Independence Scale (FIM) tests. The data were retrospectively evaluated and recorded.

Results: The mean stroke duration was $15.38 \pm 7.16$ months. According to Spearman correlation test results, there was no correlation between ARAT and PASS $(p=0.902)$, PASS-BADL (Basic activities of daily living) $(\mathrm{P}=0.480)$, PASS-IADL (Instrumental activities of daily living) $(p=0.524)$ and between ARAT and FIM ( $p=0.45 \mathrm{I})$, FIM Motor $(p=0.393)$, and FIM Cognitive $(p=0.553)$. There was a weak correlation between the FIM and the PASS scores $(r=0.278$, $\mathrm{p}=0.033$ ).

Conclusion: ARAT scores routinely used in the evaluation of upper extremity motor functions were not correlated with functional independence. In addition to the ARAT test, functional independence scales may be appropriate for the evaluation of upper extremity motor functions.

\section{INTRODUCTION}

According to the World Health Organization, stroke is a rapidly evolving clinical manifestation due to a local or general impairment of cerebral function without any cause other than vascular causes, resulting in death or for lasting longer than 24 hours. ${ }^{[1,2]}$ Stroke is a common neurological problem and one of the major causes of disability and death. ${ }^{[3,4]}$ In patients with stroke, the morbidity rate is high. Therefore, stroke is one of the main causes of increasing health expenditures in adulthood. ${ }^{[5]}$ It has been shown that post-stroke rehabilitation may be effective in improving stroke symptoms and reducing long-term worse effects. ${ }^{[6,7]}$

Impaired hand movements and dexterity occur in $60 \%$ of the patients with stroke. Hand dexterity reflects the individual's performance in daily living activities; therefore, one of the most important goals of strok/e rehabilitation is the recovery of upper limb functions. ${ }^{[8]}$ There are many studies that investigate the scales measuring the efficacy and safety of the treatments used to achieve this recovery. [9,10] In the patients with stroke with upper extremity involvement, several measurement methods are available to predict both the degree of disability and the follow-up of the clinical course. ${ }^{[11-13]}$

Action Research Arm Test (ARAT) is one of the most commonly used scoring methods for motor evaluation of upper extremity in stroke. ARAT measures the ability to use and carry large or small objects qualitatively concerning dexterity and proximal muscle strength in both upper extremities. ${ }^{[1]}$ ARAT is a reliable and valid scoring method for stroke patients. ARAT consists of a total of 19 functional materials and four subtests as follows: grasp, grip, pinch, and gross movement. The total normal score is 57 . According to the upper extremity functional capacity, test scores are evaluated as no capacity ( 0 to 10 points) and full capacity (54 to 57 points). ${ }^{[12,14]}$ 
Functional independence is the main goal of stroke rehabilitation. Although there are many scaling methods to evaluate the functional independence, the ability to predict functional independence of these methods is still controversial. $^{[15,16]}$

Functional Independence Scale (FIM) is one of the most commonly used, valid and reliable methods to measure the patients' independence in daily life activities. ${ }^{[17]}$ The Functional Independence Measure is used to assess the functional course of patients and to test the reflection of benefit from rehabilitation to daily living activities. Functional Independence Measure consists of 18 items with observational and questionnaire categories. Each activity (eating, self-care, dressing, toilet use, etc.) is scored from I to 7 (I: fully dependent, 7: fully independent). The total score is 126. ${ }^{[16]}$

Performance Assessment of Self-Care Skills (PASS) is another scaling method that evaluates functional independence. ${ }^{[18]}$ The PASS consists of 26 items and four different categories: five functional mobility, three basic daily living activities, 14 instrumental daily living activities-cognitive, and four instrumental daily living activities-physical. Each category is scored from 0 to 3 . Functional independence increases as the score increases. ${ }^{[19]}$

The ARAT has measured the efficiency of the treatment by evaluating the upper extremity motor functions before and after treatment in stroke patients. However, in addition to ARAT scores, functional independence scales are often used to assess the independence of the patient is in daily living activities in response to the treatment. ${ }^{[20]}$

In this study, we aimed to evaluate the correlation of ARAT with functional independence scales and to investigate whether it can predict functional independence alone without using an additional scoring in stroke patients with upper extremity dysfunction.

\section{MATERIALS AND METHODS}

In this retrospective cohort study, ischemic and hemorrhagic stroke patients with upper extremity dysfunction who applied to the stroke outpatient clinic of Bolu Abant Izzet Baysal University Training and Research Hospital between January 2018 and February 2019 were included. Considering that it may affect functional independence independent of upper extremity weakness, patients with a Mini-Mental State Examination (MMSE) score of less than 25, motor, sensory or global aphasia, National Stroke Health Scale Score (NIHSS) $>5$, and a premorbid Modified Rankin Score (MRS) score $>2$ were excluded from this study. After approval from the local editorial board, demographic data, ARAT, FIM, PASS, Modified Ashworth Scale (MAS) for biceps brachii and triceps muscles, and NIHSS scores of the patients included in this study were recorded retrospectively.

\section{Action Research Arm Test (ARAT)}

ARAT assesses the upper extremity function with 19 items on four subsections (grasp, grip, pinch, gross arm movement). Each item rates performance between $0-3$ scores. If patients score 3 on the first items of a section, the patient gets full score all subsequent items on that subscale. Possible score range between $0-57$ and higher scores indicates better function. The test requires various sized wooden blocks, balls, tubes bolts and marbles. The test was performed while the patient was sitting on an armchair in front of a table and test items placed on the table one by one.

\section{Functional Independence Measure (FIM)}

The test used for measuring the level of patients disability and how much assistance required to carry out daily living activities. The test consists of 18 items. The first 13 items focus on motor tasks and the last five items focus on cognitive tasks. Items are rated on a 7 points scale from total assistance to complete independence. Higher scores indicate better independence.

\section{Performance Assessment of Self-Care Skills (PASS)}

The test uses 26 items on four subsections to assess selfcare skills. Each item rates from 0-3. Higher scores indicate better independence and the highest possible score is 78. Tests overall scores divide into subscores as basic activities of daily living (PASS-BADL) and instrumental activities of daily living (PASS-IADL).

\section{Modified Ashworth Scale (MAS)}

This scale used to assess the spasticity of upper extremity muscles (biceps brachii and triceps). Test scores level of spasticity with 6 points ordinal scale between $0-3(0,1$, $\mathrm{I}+, 2,3,4)$. Higher scores indicate increased spasticity. The test was performed while patients on the supine position and their effected extremity assessed with a motion matches the normal speed of extremity.

\section{National Institutes of Health Stroke Scale (NIHSS)}

This test measures the severity of symptoms that originated from cerebrovascular incidents as a quantitative measurement. The test consists of 15 items that require answering questions or obeying simple commands, deviation of gaze, the severity of hemianopsia, papillary response, fascial palsy, reflexes, ataxia, sensory and motor function, neglect, and aphasia. Items rated on a 0-3/4 ordinal scale and the highest possible score is 42 . Higher scores indicate higher severity. ${ }^{[21]}$

SPSS Windows 22.0 (SPSS Inc., Chicago, IL, USA) was used for data analysis. Descriptive data were given as mean \pm standard deviation (SD). The correlation analysis between ARAT scores and FIM and PASS scores, and FIM scores and PASS scores was performed by Spearman correlation analysis. A p-value $<0.05$ was considered statistically significant.

\section{RESULTS}

Of the 59 patients with a mean age of $61.10 \pm 9.12,41$ $(69.5 \%)$ were males and $18(30.5 \%)$ were females. Forty- 
Table I. Baseline characteristics

\begin{tabular}{|c|c|c|c|}
\hline & \multicolumn{3}{|c|}{$n=59$} \\
\hline & $\mathbf{n}$ & $\%$ & Mean $\pm S D$ \\
\hline Mean age & & & $61.10 \pm 9.12$ \\
\hline Mean stroke onset & & & $15.38 \pm 7.16$ \\
\hline MMSE score & & & $27.52 \pm 1.87$ \\
\hline NIHSS & & & $2.59 \pm 1.70$ \\
\hline \multicolumn{4}{|l|}{ MAS } \\
\hline 0 & 7 & 11.9 & \\
\hline I & 21 & 35.6 & \\
\hline $1+$ & 15 & 25.4 & \\
\hline 2 & 16 & 27.1 & \\
\hline \multicolumn{4}{|l|}{ Gender } \\
\hline Male & 41 & 69.5 & \\
\hline Female & 18 & 30.5 & \\
\hline \multicolumn{4}{|l|}{ Affected side } \\
\hline Right & 32 & 54.2 & \\
\hline Left & 27 & 45.8 & \\
\hline \multicolumn{4}{|l|}{ Stroke type } \\
\hline Ischemic & 49 & 83.1 & \\
\hline Hemorrhagic & 10 & 16 & \\
\hline
\end{tabular}

P<0.05. SD: Standard deviation; MMSE: Mini-mental State Examination; NIHSS: National Institutes of Health Stroke Scale; MAS: Modified Ashworth Scale.

nine patients $(83.1 \%)$ had an ischemic stroke and 10 patients $(16.9 \%)$ had a hemorrhagic stroke. The mean stroke duration was $15.38 \pm 7.16$ months. The mean MMSE score was 27.52 \pm I.87. The mean NIHSS scores were $2.59 \pm 1.70$ The demographic data, clinical characteristics and the mean values of evaluation scales of the patients are given in Table I. According to Spearman correlation test results, there was no correlation between ARAT and PASS $(p=0.902)$, PASS-BADL $(p=0.480)$, PASS-IADL $(p=0.524)$ and between ARAT and FIM $(p=0.45 \mathrm{I})$, FIM Motor $(p=0.393)$, and FIM Cognitive $(p=0.553)$. The FIM and the PASS scores of the patients were significantly correlated $(r=0.278, p=0.033)$ (Table 2, Fig. I).

\section{DISCUSSION}

In the present study, it was investigated whether there was a relationship between ARAT scores used in the eval-
Table 2. Spearman correlation between motor and functional independence scales

\begin{tabular}{lcr}
\hline & \multicolumn{2}{c}{ Spearman correlation } \\
\cline { 2 - 3 } & $\mathbf{r}$ & $\mathbf{p}$ \\
\hline ARAT & & \\
FIM total & -0.100 & 0.451 \\
FIM cognitive & -0.079 & 0.553 \\
FIM motor & -0.113 & 0.393 \\
PASS & 0.016 & 0.902 \\
PASS-BADL & -0.094 & 0.480 \\
PASS-IADL & 0.085 & 0.524 \\
FIM vs PASS & 0.278 & 0.033 \\
\hline
\end{tabular}

ARAT: Action Research Arm Test; PASS: Performance Assessment of Self Care Skills; IADL: Instrumental activities of daily living; BADL: Basic activities of daily living; FIM: Functional Independence Measure; r: Spearman Correlation Coefficient. $P<0.05$.

uation of upper extremity motor functions and FIM and PASS scores, which are functional independence scales in stroke patients; however, no correlation was found. Both functional independence scales were correlated with each other.

In a population-based study, it was observed that approximately $21 \%$ of the patients could not regain functional independence of the upper extremity despite comprehensive rehabilitation. ${ }^{[22]}$

Functional limitation can be described as a limitation or lack of performing an action. The inability to dress without any support can be given as an example of the functional limitation of the upper extremity. ${ }^{[23]}$ ARAT is a test for evaluating the motor functions of upper extremity in patients with cerebral impairment. ${ }^{[12]}$ The ARAT has been reported to be a sufficient method to demonstrate the use of upper extremity in functional activities after stroke from the first few weeks to the first months. ${ }^{[23]}$ The PASS and the FIM are two important measuring functional performance of the patients. ${ }^{[16,18]}$

In a study conducted by Rabadi et al., ${ }^{[24]}$ the ARAT scores were compared with the Fugl-Meyer Assessment (FMA), another motor functional scale, as measures of upper-extremity motor weakness in stroke patients. ARAT scores were found to be correlated with FMA scores. Additionally, both the ARAT and FMA scores were found to be (a)

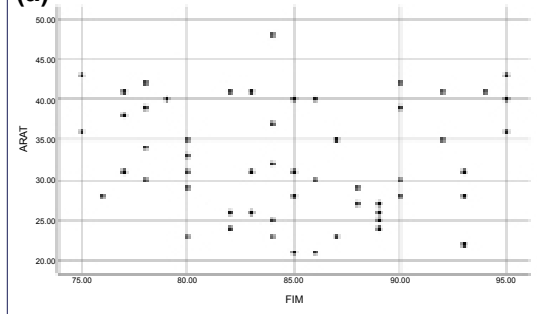

(b)

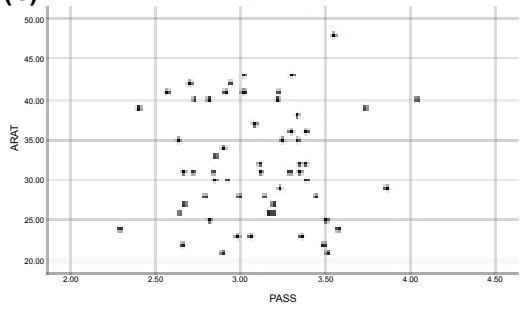

(c)

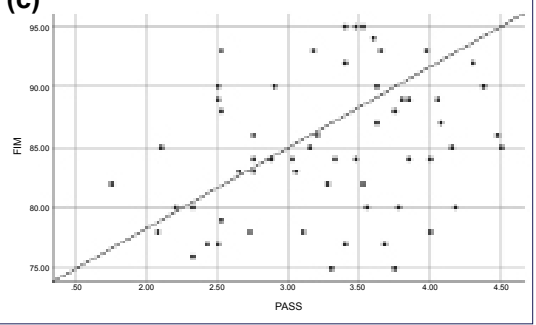

Figure 1. Correlation between motor and functional independence scales. ARAT: Action Research Arm Test; PASS: Performance Assessment of Self Care Skills; FIM: Functional Independence Measure. 
correlated with the FIM total and FIM activities of daily living sub-scores on admission and discharge. However, they stated in the study limitation that the patients might achieve high functional independence based on FIM scores without any significant improvement in motor functions using the unimpaired limb or an assistive device. In our study, in contrast to Rabadi's study, we did not have any intervention to the patients and only admission ARAT and functional independence scores were compared, and we did not find any correlation. The study conducted by Fong et al. ${ }^{[25]}$ evaluated the motor and functional performance of acute stroke patients. They used FMA for motor performance and FIM motor subscale for functional performance. They found a correlation between the FMA and the FIM motor sub-scores in both lower and upper extremities on admission, but they did not find any correlation between the motor and the functional scores in the upper extremity in the $2^{\text {nd }}$ week after the rehabilitation. In the present study, the patients with stroke with subacute and chronic phases were included. Consistent with the results of Fong's et al.'s study, there was no correlation between upper extremity motor scores and functional independence in the subacute and chronic phase.

For tasks requiring the use of the hand, patients commonly perform these tasks with the unaffected side. This may explain the lack of correlation between upper extremity motor performance and functional performance in stroke patients in our study. In our study, the mean value of stroke onset was found to be 13 months. There are studies reporting that the ARAT is efficient, demonstrating the functionality in the early stage of stroke. However, in the transition from the acute phase to the subacute and chronic phase, it has been reported that the ARAT is insufficient to reflect the functionality of upper extremity. ${ }^{[25]}$

The main limitation of the current study is the small sample size and single-center design. Multicentric and large sample-sized studies are needed to investigate the correlation between ARAT and functional independence scales. Another limitation of our study is that only admission scores were compared and the scores after the rehabilitation were not investigated.

In the present study, the findings showed that ARAT scores routinely used to evaluate upper extremity motor functions in stroke patients did not correlate with functional independence scores. In addition to ARAT, functional independence tests, such as PASS or FIM, are required to evaluate the ability of the ARAT test to predict functional independence in the evaluation of upper extremity motor functions in patients with stroke.

Ethics Committee Approval

The study was performed in accordance with the Declaration of Helsinki's Good Clinical Practice guidelines and approved by the Bolu Abant İzzet Baysal Clinical Researches Ethics Committee (date: 2017, no: 147).

Peer-review

Internally peer-reviewed.
Authorship Contributions

Concept: M.N.Ö., R.K.; Design: M.N.Ö.; Supervision: M.N.Ö.; Fundings: M.N.Ö.; Materials: M.N.Ö., R.K.; Data: R.K.; Analysis: M.N.Ö., R.K.; Literature search: R.K.; Writing: M.N.Ö., R.K.; Critical revision: M.N.Ö.

Conflict of Interest

None declared.

\section{REFERENCES}

1. Mathers C, Fat DM, Boerma J. The global burden of disease: 2004 update: World Health Organization; 2008. Available at: https://www. who.int/healthinfo/global_burden_disease/GBD_report_2004update_full.pdf. Accessed Apr 11, 2020.

2. Aho K, Harmsen P, Hatano S, Marquardsen J, Smirnov VE, Strasser T. Cerebrovascular disease in the community: results of a WHO collaborative study. Bull World Health Organ 1980;58:113-30.

3. Sims NR, Muyderman H. Mitochondria, oxidative metabolism and cell death in stroke. Biochim Biophys Acta 2010;1802:80-91. [CrossRef]

4. Bilir Kaya B, Süslü S. Role of Gender in the Quality of Life and Functional Status in Stroke Patients with Urinary Incontinence. South Clin Ist Euras 2019;30(1):77-82. [CrossRef]

5. Levine DA, Morgenstern LB, Langa KM, Piette JD, Rogers MA, Karve SJ. Recent trends in cost-related medication nonadherence among stroke survivors in the United States. Ann Neurol 2013;73:180-8. [CrossRef]

6. Sandercock P, Berge E, Dennis M, Forbes J, Hand P, Kwan J, et al. A systematic review of the effectiveness, cost-effectiveness and barriers to implementation of thrombolytic and neuroprotective therapy for acute ischaemic stroke in the NHS. Health Technol Assess 2002;6:1-112.

7. Wainapel SF, Fast A. Alternative medicine and rehabilitation: a guide for practitioners. Demos Medical Publishing; 2003. p. 277-92.

8. Nomikos PA, Spence N, Alshehri MA. Test-retest reliability of physiotherapists using the action research arm test in chronic stroke. J Phys Ther Sci 2018;30:1271-7. [CrossRef]

9. Sheikh K. Disability scales: assessment of reliability. Arch Phys Med Rehabil 1986;67:245-9.

10. van der Lee JH, Wagenaar RC, Lankhorst GJ, Vogelaar TW, Devillé WL, Bouter LM. Forced use of the upper extremity in chronic stroke patients: results from a single-blind randomized clinical trial. Stroke 1999;30:2369-75. [CrossRef]

11. Hsieh CL, Hsueh IP, Chiang FM, Lin PH. Inter-rater reliability and validity of the action research arm test in stroke patients. Age Ageing 1998;27:107-13. [CrossRef]

12. Lyle RC. A performance test for assessment of upper limb function in physical rehabilitation treatment and research. Int J Rehabil Res 1981;4:483-92. [CrossRef]

13. Lin JH, Hsu MJ, Sheu CF, Wu TS, Lin RT, Chen CH, et al. Psychometric comparisons of 4 measures for assessing upper-extremity function in people with stroke. Phys Ther 2009;89:840-50. [CrossRef]

14. Hsieh YW, Wu CY, Lin KC, Chang YF, Chen CL, Liu JS. Responsiveness and validity of three outcome measures of motor function after stroke rehabilitation. Stroke 2009;40:1386-91. [CrossRef]

15. McKenna H, Cutcliffe J, McKenna P. Evidence-based practice: demolishing some myths. Nurs Stand 2000;14:39-42. [CrossRef]

16. Valach L, Selz B. Rehabilitation Programs monitored by Functional Independence Measure: An Observational Study. Int Phys Med Rehab J 2017;2:173-8. [CrossRef]

17. Granger CV, Hamilton BB, Linacre JM, Heinemann AW, Wright BD. Performance profiles of the functional independence measure. Am J Phys Med Rehabil 1993;72:84-9. [CrossRef] 
18. Holm MB, Rogers JC, Hemphill-Pearson B. The performance assess-ment of self-care skills (PASS). Assessments in occupational therapy mental health. 2 ed. SLACK; 2008. p. 101-10.

19. Chisholm D, Toto P, Raina K, Holm M, Rogers J. Evaluating capacity to live independently and safely in the community: Performance Assessment of Self-care Skills. Br J Occup Ther 2014;77:59-63.

20. Ottenbacher KJ, Hsu Y, Granger CV, Fiedler RC. The reliability of the functional independence measure: a quantitative review. Arch Phys Med Rehabil 1996;77:1226-32. [CrossRef]

21. Stegmayr B, Asplund K. Exploring the declining case fatality in acute stroke. Population-based observations in the northern Sweden MONICA Project. J Intern Med 1996;240:143-9. [CrossRef]
22. Nakayama H, Jørgensen HS, Raaschou HO, Olsen TS. Recovery of upper extremity function in stroke patients: the Copenhagen Stroke Study. Arch Phys Med Rehabil 1994;75:394-8. [CrossRef]

23. Lang CE, Wagner JM, Dromerick AW, Edwards DF. Measurement of upper-extremity function early after stroke: properties of the action research arm test. Arch Phys Med Rehabil 2006;87:1605-10. [CrossRef]

24. Rabadi MH, Rabadi FM. Comparison of the action research arm test and the Fugl-Meyer assessment as measures of upper-extremity motor weakness after stroke. Arch Phys Med Rehabil 2006;87:962-6.

25. Fong KN, Chan CC, Au DK. Relationship of motor and cognitive abilities to functional performance in stroke rehabilitation. Brain Inj 2001;15:443-53. [CrossRef]

\section{Kol Hareket Araştırma Testi İnmeli Hastalarda Fonksiyonel Bağımsızlığı Ön Gördürebilir mi?}

Amaç: İnmeli hastalarda üst ekstremite motor fonksiyonlarının değerlendirilmesinde kullanılan Kol Hareket Araştırma Testi (ARAT) skorlarının fonksiyonel bağımsızı̆ı̆ı ön görebilme kapasitesini araştırmak.

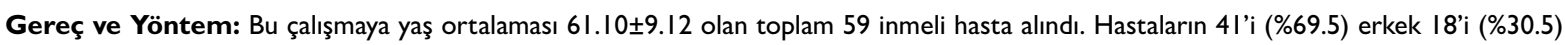
kadındı. İnme sonrası inme polikliniğinde takip edilen hastaların demografik bilgileri alındıktan sonra üst ekstremite fonksiyonları ARAT testi ve fonksiyonel bağımsızlıkları Kendine Bakım Becerilerin Performans Değerlendirmesi (PASS) ve Fonksiyonel Bağımsızlık Ölçeği (FIM) testleri ile değerlendirildi.

Bulgular: Hastaların ortalama inme geçirme süreleri $15.38 \pm 7.16$ ay olarak bulundu. Spearman korrelasyon testi sonuçlarına göre ARAT ve PASS arasında $(p=0.902)$, PASS-BADL (temel günlük yaşam aktiviteleri) $(p=0.480)$, PASS-IADL (enstrümental günlük yaşam aktiviteleri) $(p=0.524)$ ARAT ve FIM $(p=0.45 \mathrm{I})$, FIM Motor $(p=0.393)$ ve FIM Cognitive $(p=0.553)$. arasında korelasyon görülmedi). FIM ve PASS skorları arasında zayıf bir korelasyon vardı $(r=0.275, p=0.033)$.

Sonuç: Üst ekstremite motor fonksiyonlarının değerlendirilmesinde rutin olarak kullanılan ARAT skorları fonksiyonel bağımsızlık ile korele olmadığı saptandı. Üst ekstremite motor fonskiyonlarının değerlendirilmesinde ARAT testine ek olarak fonksiyonel bağımsızlık ölçeklerinin kullanılması uygun olabilir.

Anahtar Sözcükler: Fiziksel fonksiyonel bağımsızlık; inme; üst ekstremite. 